\title{
Treasury and Federal Reserve Foreign Exchange Operations
}

This report, presented by Dino Kos, Senior Vice President, Federal Reserve Bank of New York, and Manager, System Open Market Account, describes the foreign exchange operations of the U.S. Department of the Treasury and the Federal Reserve System for the period from April 2001 through June 2001. Krista Schwarz was primarily responsible for preparing the report.

During the second quarter of 2001, the dollar appreciated 3.3 percent against the euro and depreciated 1.2 percent against the yen. On a trade-weighted basis, the dollar ended the quarter nearly unchanged against the currencies of the United States' major trading partners. Over the quarter, market perceptions that the U.S. economy would emerge from its downturn sooner than the euro area provided underlying support for the dollar. The U.S. monetary authorities did not intervene in the foreign exchange markets during the quarter.

\section{PROSPECTS FOR AN ECONOMIC TURNAROUND DRIVE U.S. MARKET SENTTMENT}

The Federal Open Market Committee (FOMC) lowered the target federal funds rate a total of 125 basis points, from 5.0 percent to 3.75 percent, during the

1. U.S. Treasury yields, 2001:Q2

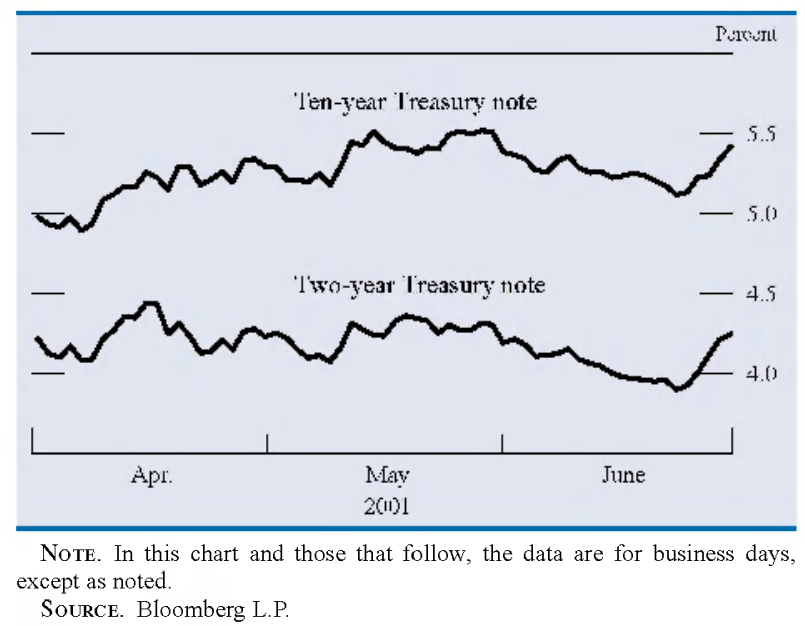

second quarter. Market participants debated the extent of the U.S. economic slowing and considered the scope for any future easing in monetary policy. Market discussion on the outlook for inflation contributed to Treasury yield curve steepening. Over the quarter, the two-year Treasury yield rose 6 basis points while the yield on the ten-year note rose 49 basis points, widening the spread between the two- and ten-year yields 43 basis points, to 117 basis points.

Early in the quarter, the release of strongerthan-expected data for GDP growth in the first quarter boosted optimism for growth prospects for the remainder of the year. Additionally, several announcements of first-quarter earnings contributed to a temporary revival in investor sentiment. Global equity indexes rallied, with the S\&P 500, the Topix (Tokyo Stock Exchange Price Index), and the DJ Euro Stoxx indexes gaining as much as 13.1 percent, 12.8 percent, and 8.8 percent respectively. However, other U.S. economic data releases, such as the March and April employment reports, suggested continued softening in some sectors of the economy, heightening expectations for further easing of monetary policy by the FOMC. Over the quarter, yields implied by the July and September federal funds futures contracts declined 59 and 58 basis points, to 3.75 percent and 3.67 percent respectively.

2. Federal funds target rate and yields implied by the July and September federal funds futures contracts, 2001:Q2

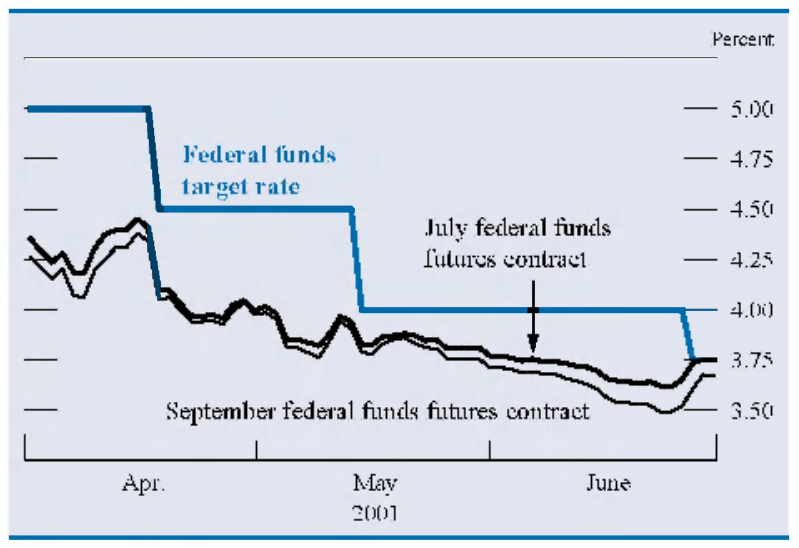

SoURCE. Bloomberg L.P. 
3. Global benchmark equity indexes, 2001:Q2

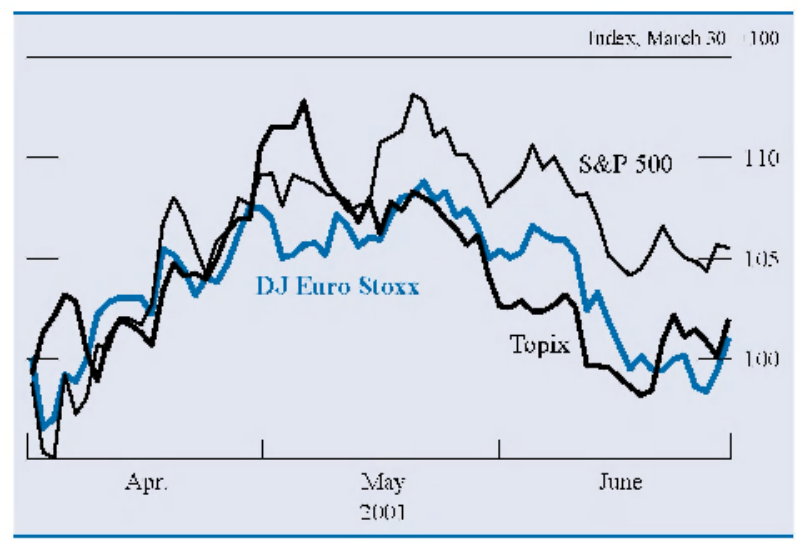

SOURCE. Bloomberg L.P.

In the second half of the quarter, additional reports of declining corporate profitability and indications of deteriorating growth in other major economies weighed broadly on sentiment. Diminished prospects for economic recovery prompted declines in global equity indexes, which pared gains made earlier in the quarter. On balance, the S\&P 500, the Topix, and the DJ Euro Stoxx indexes rose 5.5 percent, 1.9 percent, and 1.0 percent, respectively, over the second quarter.

Directional trends in major currency pairs were largely muted, and the dollar closed the quarter nearly unchanged on a trade-weighted basis. A notable decline in option implied volatility across maturities in the Group of Three currencies suggested lower investor demand for protection against sharp exchange rate movements and a greater level of comfort with recent trading ranges and directional trends. The dollar traded in a range of $\$ 0.87$ to $\$ 0.91$ against the euro and moved between $¥ 120$ to $¥ 125$ for most of the quarter. One-year dollar-yen and euro-dollar

\section{Trade-weighted Group of Three currencies, 2001:Q2}

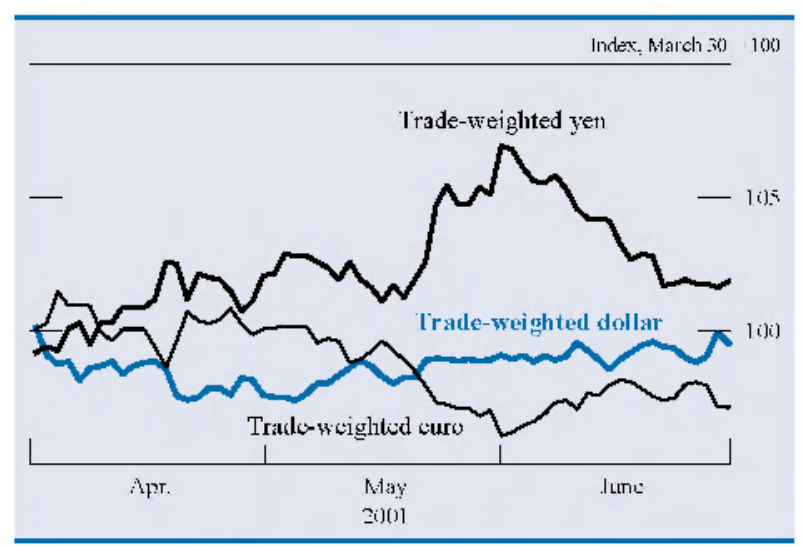

SouRcEs. Board of Governors of the Federal Reserve System, the Federal Reserve Bank of New York, and the Bank of England.
5. One-year euro-dollar and dollar-yen option implied volatility, 2001:Q2

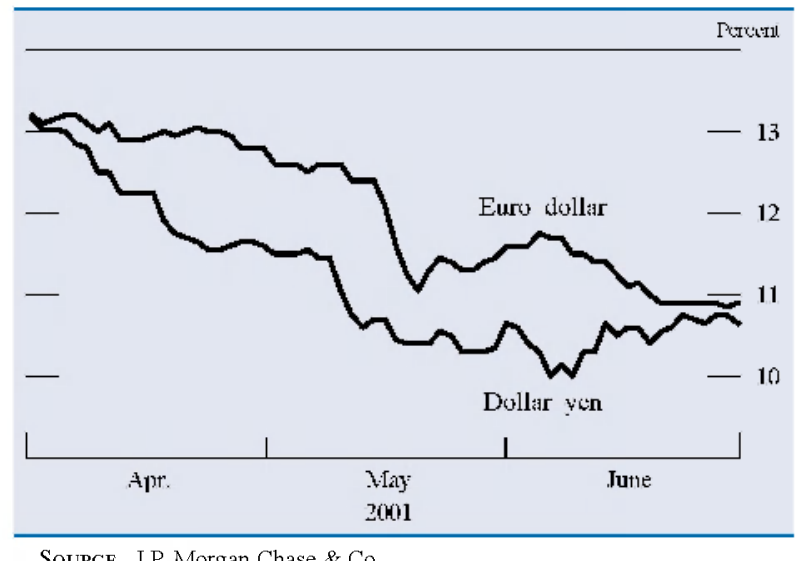

Source. J.P. Morgan Chase \& Co.

implied volatilities reached their lowest levels in more than a year and ended the quarter 2.5 and 2.3 percentage points lower, at 10.65 percent and 10.9 percent respectively.

\section{EURO-AREA COUNTRIES SHOW SIGNS \\ OF DECELERATING GROWTH; CAPITAL OUTFLOWS CONTINUE.}

The euro depreciated 3.2 percent against the dollar and 4.4 percent against the yen. After trading in a relatively narrow range against the dollar during the first half of the quarter, the euro weakened to a new low for the year. Economic data indicating slowing euro-area growth and rising inflation and debate among market participants regarding the objectives of the European Central Bank (ECB) weighed on sentiment toward the single currency. Net crossborder investment outflows and a shift in investor positioning further pressured the euro.

According to the ECB, the net outflow of direct and portfolio investment from the euro area totaled $€ 20.8$ billion in April, after an outflow of $€ 86$ billion in the first quarter of 2001. The largest outflows were by nonresidents, totaling $€ 11.3$ billion. The data seemed to corroborate anecdotal market reports that highlighted Japanese disinvestment from the euro area as the currency-adjusted value of these investments deteriorated. Additionally, after the yen's appreciation in May, positioning data from the International Monetary Market showed that net euro positions by speculative investors turned short for the first time in nine months.

Early in the quarter, euro-area economic data indicated that growth was slowing and price pressures were rising. M3 growth and headline inflation-the 
6. Currency-adjusted price returns on euro-denominated government bond index, 2001:Q2

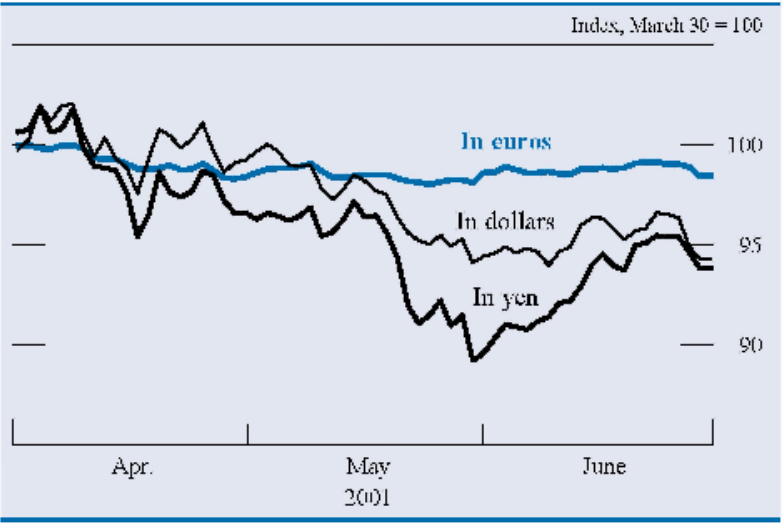

Source. Merrill Lynch

ECB's stated monetary policy pillars-remained above their respective reference values. On May 10, the ECB surprised market participants by lowering official interest rates 25 basis points, bringing the two-week marginal refinancing rate to 4.50 percent. Among the factors cited as contributing to the decision was that the ECB identified an upward distortion in data for M3 growth and a diminution of upward risks to price stability.

Later in the quarter, however, economic data for the euro area continued to show signs of rising inflation, shifting expectations for another interest rate reduction to a later date. The yield implied by the September 2001 three-month euribor futures contract rose 20 basis points, to 4.25 percent, while the yield implied by the March 2002 contract rose only 11 basis points. Meanwhile, data releases for the euro area showed continued deceleration in economic activity, most notably in Germany, lending a measure

7. Dollar-euro swap spreads, 2001:Q1 and Q2

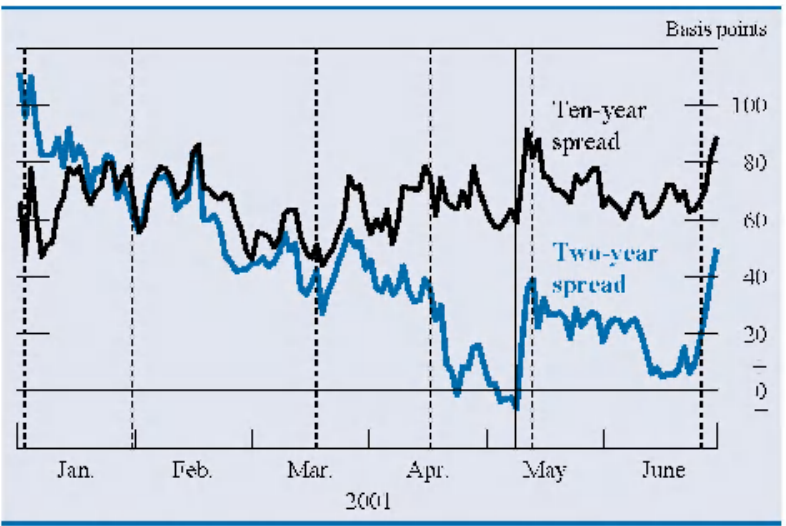

Nort. Dashed vertical lines denote interest rate cuts by the FOMIC. Solid

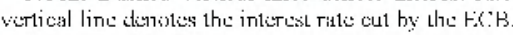

SourCE. Bloomberg L.P. of support to expectations for further easing. Additionally, the ECB and several German research institutes revised their growth projections downward for the euro area.

Although the FOMC eased policy more than the $\mathrm{ECB}$, long-dated interest rate differentials remained in favor of the dollar in the second quarter. After the ECB's May 10 move to ease rates, the spread between the ten-year swap rates for the dollar and the euro reached its widest level for the year at 91 basis points. The euro depreciated 4.6 percent against the dollar in May after the policy change. On balance over the second quarter, short-dated interest rate differentials moved further in favor of the euro but at a less rapid pace than in the first quarter.

\section{THE YEN RESPONDS TO BROAD SHIFTS IN. LOCAL 'AND INTERNATIONAL INVESTOR FLOWS}

The yen appreciated as much as 6.0 percent and 10.0 percent against the dollar and the euro before depreciating to end the quarter 1.2 percent and 4.6 percent stronger against the dollar and the euro respectively. Investor sentiment toward Japan improved after Japan's ruling party selected a new prime minister in April, and investor position adjustments contributed to yen strength in the first half of the quarter. However, signs of further economic deterioration, delays in implementing anticipated reforms, and market perceptions of official U.S. and Japanese tolerance for yen depreciation reintroduced a negative bias toward Japanese assets and contributed to the yen's subsequent decline against the dollar and the euro.

Running on a platform of widespread reform, Junichiro Koizumi became Japan's prime minister after Liberal Democratic Party members elected him as their new party leader on April 24. Prime Minister Koizumi's plans for structural reform and fiscal restraint initially boosted investor optimism toward Japanese securities, providing underlying support for the yen. Net purchases of Japanese equities by foreign investors, who many market participants estimated were underweight in Japanese stocks relative to their benchmarks, rose to their highest level since December 1999. Additionally, in mid-May, the euro's weakness and resulting Japanese investor losses reportedly led to a retrenchment of European investments by Japanese investors. The yen's initial appreciation sparked a spate of short yen position covering, further accelerating the exchange rate movement. Against this backdrop of position adjustment and capital flows, the yen appreciated sharply in late May, 
8. Foreign investor flows for Japanese equities and the Topix equity index, 2001:Q2

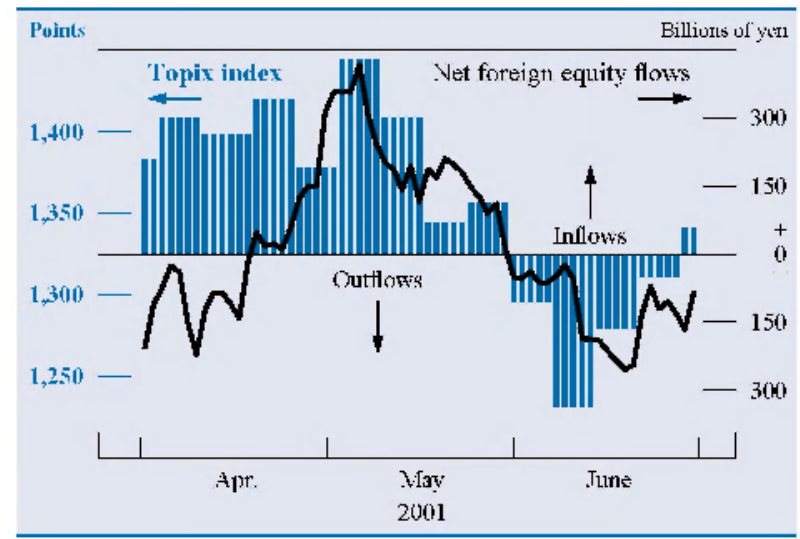

Sources. Tokyo Stock Exchange and Bloomberg L.P.

breaking below the $¥ 120$ and $¥ 101$ levels against the dollar and the euro respectively.

In June, this price action was largely reversed: The yen weakened 4.5 percent against the euro and 4.9 percent against the dollar, as post-election enthusiasm and initial hopes for specific structural reform plans began to ebb. In addition, market participants interpreted a Japanese newspaper report as suggesting that U.S. policymakers would tolerate a weaker yen exchange rate if it resulted from a restructuring of Japan's economy. Japanese economic data and downward revisions of growth forecasts reduced investor expectations for an economic recovery. Japan's trade surplus for May declined markedly, largely attributed to economic deceleration in Japan's major trading partners. According to the Tokyo Stock Exchange, net foreign buying of Japanese equities early in the quarter became net foreign selling in the second half of the quarter. The Topix subindex for the banking sector fell as much as 15 percent, reaching its lowest level since October 1998.

9. The yen against the dollar and the euro, 2001:Q2

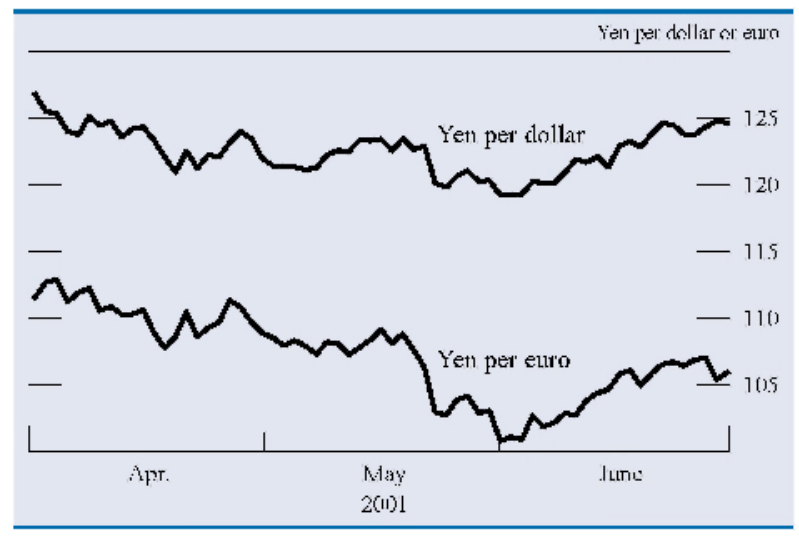

SoURCE. Bloomberg L.P.
10. Yields on short-term Japanese fixed-income securities, 2001:Q2

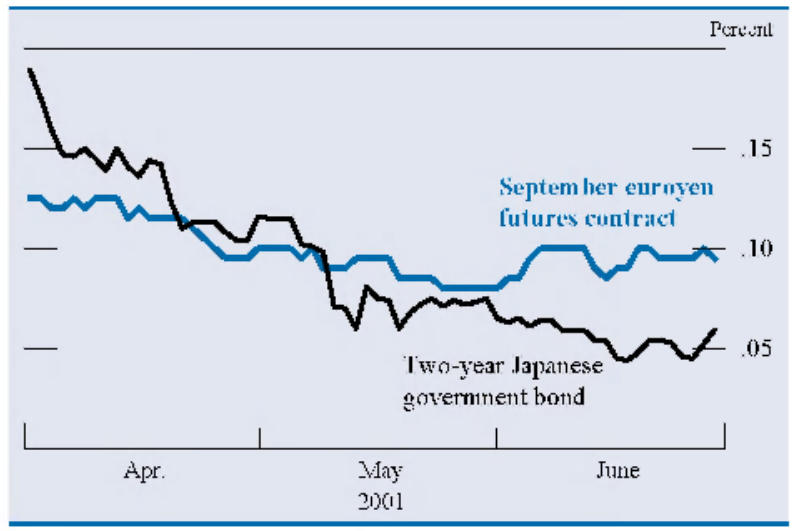

SourCE. Bloomberg L.P

In an effort to better maintain its target level of $¥ 5$ trillion in current account balances, the Bank of Japan implemented several operational changes in its money market and repurchase agreement transactions during the quarter. Market impressions that economic conditions in Japan were worsening were confirmed by economic data that showed that GDP growth was negative in the first quarter and by the Bank of Japan's downgrade of its assessment of the state of the Japanese economy. This led to market speculation that the Bank of Japan may be preparing to adopt measures to further ease its monetary policy stance, perhaps by raising its target level for financial institutions' current account balances. Reflecting a growing certainty among market participants that short-term spot interest rates will remain near zero for some time, yields implied by euro-yen futures contracts across maturities fell, and the yield on the two-year Japanese government bond declined 8 basis points, to 6 basis points.

\section{TREASURY AND FEDERAL RESERVE FOREIGN EXCHANGE OPERATIONS}

The U.S. monetary authorities did not undertake any intervention operations this quarter. At the end of the quarter, the current values of the euro and yen reserve holdings totaled $\$ 14.5$ billion for the Federal Reserve's System Open Market Account and $\$ 14.5$ billion for the U.S. Treasury's Exchange Stabilization Fund. The U.S. monetary authorities invest all of their foreign currency balances in a variety of instruments that yield market-related rates of return and have a high degree of liquidity and credit quality. To the greatest extent possible, these investments are split evenly between the Federal Reserve System and the Treasury. 
A significant portion of the U.S. monetary authorities' foreign exchange reserves is invested in government securities held outright or under repurchase agreements. During the quarter, the U.S. monetary authorities expanded the pool of euro-denominated repurchase agreement collateral that they will accept. In addition to German sovereign debt, the U.S. monetary authorities now accept sovereign debt backed by the full faith and credit of the governments of Belgium, France, Italy, the Netherlands, and Spain.

Foreign currency reserves are also invested in deposits at the Bank for International Settlements and in facilities at other official institutions. As of June 30, direct holdings of foreign government securities totaled $\$ 12.9$ billion, split evenly between the Federal Reserve's System Open Market Account and the U.S. Treasury's Exchange Stabilization Fund. Foreign government securities held under repurchase agreement totaled $\$ 2.8$ billion at the end of the quarter and were also split evenly between the two authorities.

\section{Discontinuation of "Treasury and Federal Reserve Foreign Exchange Operations" in the Federal Reserve Bulletin}

The quarterly report "Treasury and Federal Reserve Foreign Exchange Operations," by the Federal Reserve Bank of New York, will not be reprinted in the Federal Reserve Bulletin after the December 2001 issue. Each quarter's report is available soon after the end of the quarter on the web site of the Federal Reserve Bank of New York (www.newyorkfed.org/pihome/news/forex/), which also has the reports back to 1996 . The reports for years before 1996 are available in paper copies from the Public Information Department, Federal Reserve Bank of New York, 33 Liberty Street, New York, NY 10045 (tel. 212-7205424).

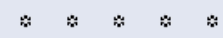

Other reprints will also be eliminated from the Bulletin after December 2001: the monthly report on industrial production and capacity utilization, congressional testimony, the FOMC minutes, and the Federal Reserve Bank of New York's annual "Open Market Operations" report (the text portion of "Open Market Operations" will be reprinted in the Board's Annual Report rather than in the Bulletin). The documents are widely distributed when originally published, and several sources for historical information are available. 
1. Foreign currency holdings of U.S. monetary authorities based on current exchange rates, 2001:Q2 Millions of dollars

\begin{tabular}{|c|c|c|c|c|c|c|c|}
\hline \multirow[b]{2}{*}{ Item } & \multirow[b]{2}{*}{$\begin{array}{c}\text { Balance, } \\
\text { Mar. 31, 2001 }\end{array}$} & \multicolumn{5}{|c|}{ Quarticrly chinetses in halimess by source } & \multirow[b]{2}{*}{$\begin{array}{c}\text { Balance, } \\
\text { June } 30,2001\end{array}$} \\
\hline & & $\begin{array}{l}\text { Net purchases } \\
\text { and sales' }\end{array}$ & $\begin{array}{l}\text { Effect of } \\
\text { sales? }\end{array}$ & $\begin{array}{l}\text { Investment } \\
\text { income }\end{array}$ & $\begin{array}{l}\text { Currency } \\
\text { valuation } \\
\text { adjustments ' }\end{array}$ & $\begin{array}{l}\text { Interest } \\
\text { accrual } \\
\text { and other }{ }^{4}\end{array}$ & \\
\hline \multicolumn{8}{|l|}{$\begin{array}{l}\text { FEDERAL RESERVE SYSTEM } \\
\text { OPEN MARKET ACCOUNT } \\
\text { (SOMA) }\end{array}$} \\
\hline 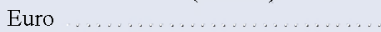 & $6,995.7$ & .0 & .0 & 81.9 & -257.2 & $\ldots$ & $6,820.4$ \\
\hline Japanese yen ............ & $7,515.3$ & .0 & .0 & 4.6 & 48.7 & $\ldots$ & $7,568.6$ \\
\hline Total & $14,511.0$ & .0 & .0 & 86.5 & -208.5 & $\cdots$ & $14,389.0$ \\
\hline Interest receivables (net) ${ }^{2}$ & 75.9 & $\ldots$ & $\ldots$ & $\ldots$ & . . & -7.6 & 68.3 \\
\hline Other cash flow from investments ${ }^{*}$ & 0 & $\cdots$ & $\cdots$ & $\cdots$ & $\cdots$ & .0 & .0 \\
\hline Total & $14,586.9$ & .0 & .0 & 86.5 & -208.5 & -7.6 & $14,457.3$ \\
\hline \multicolumn{8}{|l|}{$\begin{array}{l}\text { U.S. Treasury Exchange } \\
\text { Stabilization Fund (ESF) }\end{array}$} \\
\hline . & $6,993.5$ & .0 & .0 & 81.6 & -257.2 & $\ldots$ & $6,817.9$ \\
\hline Japanese yen & $7,515.3$ & .0 & .0 & 4.6 & 48.7 & $\ldots$ & $7,568.6$ \\
\hline Total ..... & $14,508.8$ & .0 & .0 & 86.2 & -208.5 & $\ldots$ & $14,386.5$ \\
\hline Interest receivables $^{3} \ldots \ldots \ldots \ldots$ & 72.4 & $\ldots$ & $\ldots$ & $\ldots$ & $\ldots$ & -9.7 & 67.0 \\
\hline Other cash flow from investments ${ }^{+}$ & .0 & $\ldots$ & $\ldots$ & $\ldots$ & $\ldots$ & .0 & .0 \\
\hline Total & $14,581.2$ & .0 & .0 & 86.2 & -208.5 & -9.7 & $14,453.5$ \\
\hline
\end{tabular}

NoTE. Figures may not sum to totals because of rounding.

1 Purchases and sales for the purpose of this table include foreign currency sales and purchases related to official activity, swap drawings and repayments, and warehousing.

2 This figure is calculated using marked-to-market exchange rates; it represents the difference between the sale exchange rate and the most recent revaluation exchange rate. Realized profits and losses on sales of foreign currencies, computed as the difference between the historical cost-of-acquisition exchange rate and the sale exchange rate, are reflected in table 2.
3 Foreign currency balances are marked to market monthly at month-end exchange rates.

4 Values are cash flow differences from payments and collection of funds between quarters.

$5 \quad$ Interest receivables for the ESF are revalued at month-end exchange rates. Interest receivables for the Federal Reserve System are carried at average cost of acquisition and are not marked to market until interest is paid.

$$
\text { . Nis appliciable. }
$$

2. Net profits or losses (-) on U.S. Treasury and Federal Reserve foreign exchange operations, based on historical cost-of-acquisition exchange rates, 2001:Q2

Millions of dollars

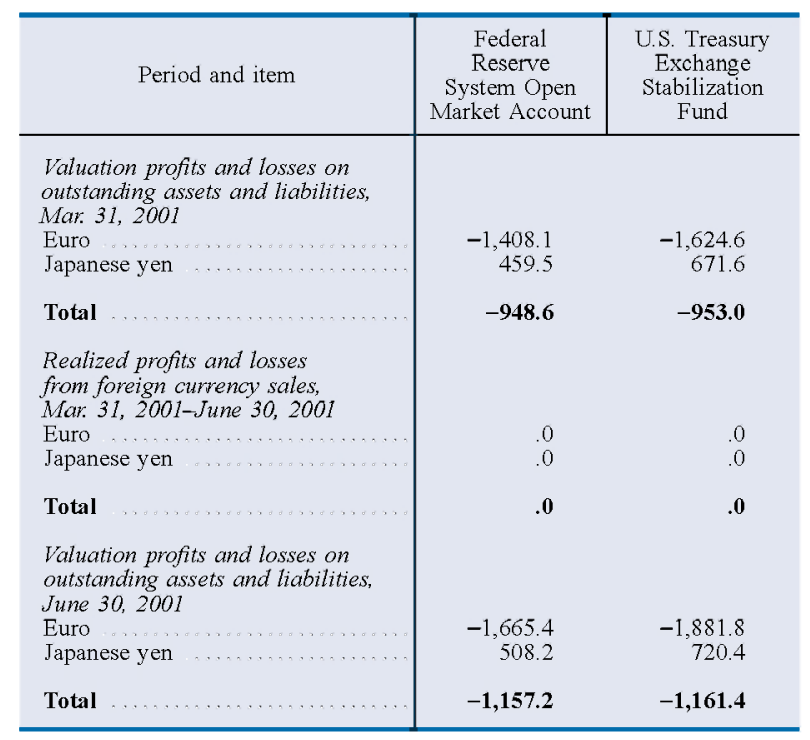

3. Reciprocal currency arrangements, June 30, 2001 Millions of dollars

\begin{tabular}{|c|c|c|}
\hline Institution & $\begin{array}{l}\text { Amount of } \\
\text { facility }\end{array}$ & $\begin{array}{l}\text { Outstanding, } \\
\text { June } 30,2001\end{array}$ \\
\hline & \multicolumn{2}{|c|}{$\begin{array}{l}\text { Reciprosal currency } \\
\text { itriingements }\end{array}$} \\
\hline $\begin{array}{l}\text { Bank of Canada ..... } \\
\text { Bank of Mexico ..... }\end{array}$ & $\begin{array}{l}2,000 \\
3,000\end{array}$ & $\begin{array}{l}.0 \\
0\end{array}$ \\
\hline \multirow[t]{2}{*}{ Total } & 5,000 & .0 \\
\hline & \multicolumn{2}{|c|}{ 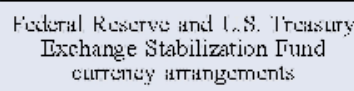 } \\
\hline Bank of Mexico. & 3,000 & .i) \\
\hline Total & 3,000 & .0 \\
\hline
\end{tabular}

